\title{
会告 - 案内 目次
}

\begin{tabular}{|c|c|c|}
\hline \multirow[t]{6}{*}{ おしらせ } & 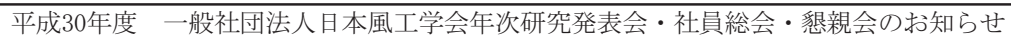 & 110 \\
\hline & 第10回日本風工学会若手スクールのお知らせ & 112 \\
\hline & 「風環境に関する情報発信研究会」委員公募のお知らせ & 113 \\
\hline & 「実大ストームシミュレータの設計と要素技術に関する研究会」委員公募のお知らせ & 114 \\
\hline & 「耐風構造教材制作研究会」委員公募のお知らせ & 115 \\
\hline & 学術研究会の公募のお知らせ & 116 \\
\hline \multirow[t]{7}{*}{ 委員会報告等 } & 一般社団法人日本風工学会 第4期（通算第21期）第9回理事会 議事録 & 117 \\
\hline & 一般社団法人日本風工学会＼cjkstart第4期（通算第21期）第8回運営・学術委員会 報告 & 121 \\
\hline & 一般社団法人日本風工学会＼cjkstart第4期（通算第21期）第7回編集・広報委員会＼cjkstart報告 & 122 \\
\hline & 一般社団法人日本風工学会＼cjkstart第4期（通算第21期）第8回編集・広報委員会＼cjkstart報告 & 123 \\
\hline & 一般社団法人日本風工学会＼cjkstart第4期（通算第21期）第4回表彰委員会＼cjkstart報告 & 124 \\
\hline & 一般社団法人日本風工学会＼cjkstart第4期（通算第21期）第7回風災害調查連絡委員会 報告 & 125 \\
\hline & 一般社団法人日本風工学会 第4期（通算第21期）第8回風災害調查連絡委員会 報告 & 125 \\
\hline 国際会議紹介 & 今後開催予定の国際会議等 & 126 \\
\hline 会員の異動等 & 会員の異動 & 127 \\
\hline \multirow[t]{4}{*}{ 各種申し込み用紙等 } & 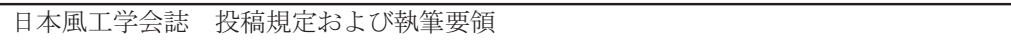 & 129 \\
\hline & 日本風工学会誌 投稿申込書 & 133 \\
\hline & 日本風工学会誌 特集 企画書 & 134 \\
\hline & 入会のご案内, 入会申込書 & 巻末 \\
\hline
\end{tabular}




\section{平成 30 年度 一般社団法人日本風工学会 \\ 年次研究発表会·社員総会·懇親会のお知らせ}

平成 30 年度一般社団法人日本風工学会年次研究発表会, 定時社員総会は, 平成 30 年 5 月 23 日

（水）に東京大学浅野キャンパスで開催されます。本年度は 3 つの学術研究会の研究報告を行い ます。また, 元会長の田村幸雄先生が，中国工程院の外籍院士に選出されたことを記念した特別 講演も企画しました。会員の皆様におかれましては，奮ってご参加いただけますようお願い申し 上げます。

\section{記}

日 時: 平成 30 年 5 月 23 日（水）

研究発表会 9:20～17:35（特別講演 11:35～12:05）

社 員 総会 17:50 19:00

懇 親 会 19:00〜20:30

場 所: 東京大学 浅野キャンパス 武田先端知ビル 5 階 武田ホール

アクセス : http://www.u-tokyo.ac.jp/campusmap/cam01_04_16_j.html

参 加 費: 研究発表会 無料 (非会員 5,000 円)

懇 親 会 5,000 円（学生会員無料）（予定）

プログラム（予定）：

9:20 開会挨拶（運営・学術委員会 委員長）

9:25 企画セッション 1： 太陽光発電システムの耐風設計

[太陽光発電システム風荷重評価研究会 研究報告]

1. 趣旨説明 (研究内容の概説)

(植松康, 東北大学)

2 ，強風被害の実状と耐風設計マニュアル作成の背景

3. 太陽光発電システムの風荷重に影響を与える要素

(高森浩治, 奥地建産)

4. 太陽光発電システムの構造設計についての解説

(染川大輔，大林組）

(新久保達也, N T T

ファシリティーズ)

5. 今後の課題

(吉田昭仁，東京工芸大学）

11:35 特別講演「日本で風工学を実践し、いま中国」（仮題）（田村幸雄先生）

12:05 昼休み

13:25 企画セッション 2： 市街地風環境評価の課題と「都市の風影響評価研究会」の取り組み [都市の風影響評価研究会 研究報告]
1. 趣旨説明
(富永禎秀, 新潟工科大学)
2. ビル風問題の年譜
(中村良平，大成建設)
3。自治体におけるビル風に関する環境影響評価の実態調査
4. 住民参加型の風環境調査事例
(作田美知子，三井住友建設）
5. スマホでつくる“暑さマップ”
(白澤多一，大妻女子大学)
6. 質疑・まとめ
(浅輪貴史, 東京工業大学)
(佐々木澄 清水建設)

15:35 企画セッション3： 実大ストームシミュレータの実現に向けて

[実大ストームシミュレータ研究会 研究報告]
1. 実大ストームシミュレータの概要説明
(田村幸雄, 重慶大学)
2. 実大ストームシミュレータ研究会報告
(西嶋一欽, 京都大学)
3. 実大ストームシミュレータを対象とした 
数值流体解析

4. 風洞装置を用いた雪水の実大実験について

5。鉄道における風災害に関連した課題と 実大ストームシミュレータへの期待

6. 森林・林業の気象害研究における 実大ストームシミュレータの活用

7. 温室から見た実大ストームシミュレータへの期待（森山英樹, 農村工学研究所)
（Pham Van Phuc，清水建設）

(堤 拓哉, 北方建築総合建築所)

（鈴木博人，JR 東日本防災研究所）

（鈴木 覚，森林総合研究所）

17:50 定時社員総会

19:00 懇親会

※タイトルおよび発表者は変更になる場合があります。

会場案内図：

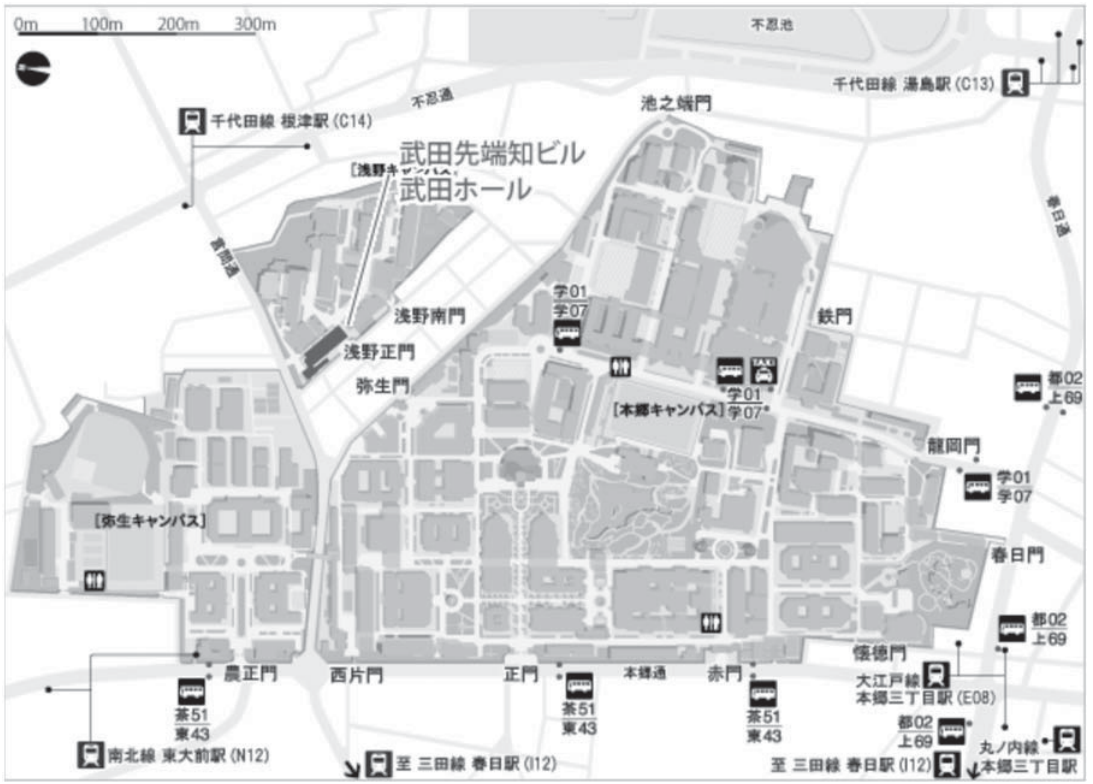




\section{第 10 回日本風工学会若手スクールのお知らせ}

近い将来, 日本風工学会の担い手となる大学院生（博士課程の学生を優先します）と若手研究者の方々を対 象に, 「第 10 回日本風工学会若手スクール」を平成 30 年度年次研究発表会の前日に開講いたします。奮ってご 参加下さいますよう, お願い申し上げます。定員は 20 名ほどを予定していますが，申込者が多数となった場合 は受付を締め切る場合がございますので，早めのお申し込みをお願い致します。

日時： 平成30年5月22日（火）

会場： セミナー・見学会 : 国立研究開発法人 宇宙航空研究開発機構（JAXA）

調布航空宇宙センター

（東京都調布市深大寺東町7-44-1 http://www.jaxa.jp/about/centers/cac/index_j.html）

懇談会：調布近郊（参加者に別途連絡）

参 加 費： 正会員・賛助会員 1,000 円（懇親会費）学生会員 無料

※賛助会員の場合 1 社 2 名までとさせていただきます。

申 込 先： 佐々木澄（清水建設）E-mail : k_sasaki@shimz.co.jp

参加を希望される方は,

(1)氏名・フリガナ，(2)所属，(3)所在地（郵便番号・住所），(4)連絡先（TEL・E-mail） を佐々木までE-mailにてご連絡下さい。

詳細については申し込みされた方にメールにてご連絡します。

\section{【スクールの概要】}

今年の若手スクールでは,「風と航空宇宙工学」 をテーマに国立研究開発法人宇宙航空研究開発機 構（JAXA）調布航空宇宙センターを見学します。 スクールは JAXA の複数の施設の見学と, 研究員 の方から風に関わる研究のレクチャーで構成寸る 予定です。

あわせてセミナー・見学会終了後には参加者の懇 談会を企画しています。参加者には短い研究紹介を お願いし, 懇談会を通じて親睦と交流を図りたいと 思います。なお，宿泊費ならびに会場までの交通費 は各自でご負担下さい。

\section{【プログラム】（予定）}

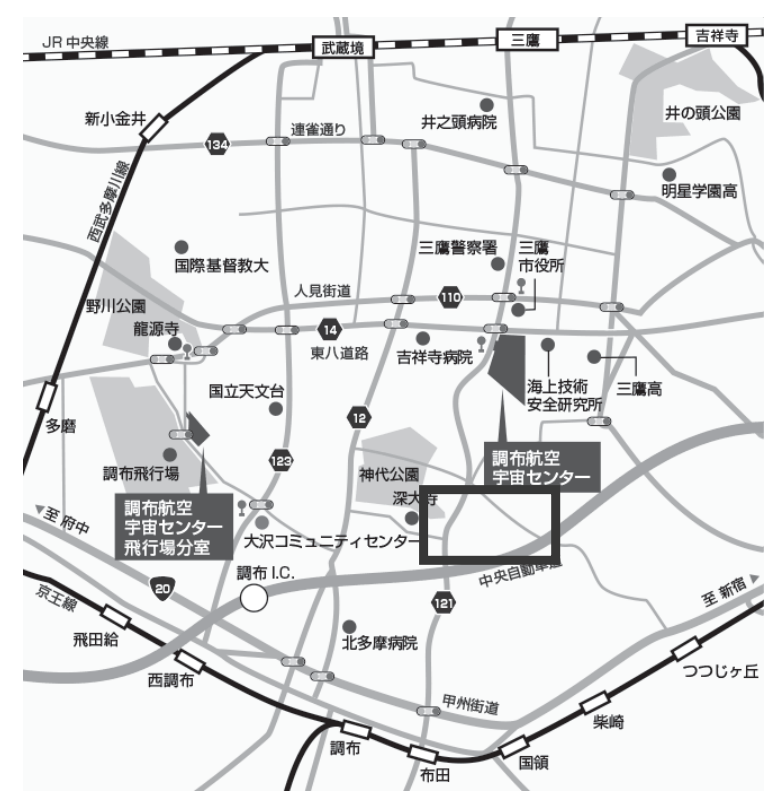

12:45 現地集合 ※

13:15 14:00 スーパーコンピューター関係の見学

14:00〜15:00 エンジン関係の見学

15:00 15:30 展示室見学

15:30 約 1 時間 風に関連する研究の講義, 質疑応答

講義終了後 17:00 風洞見学（調整中）

17:00 頃 セミナー・見学会終了 
18:00 頃 懇親会（調布近郊）

20:00 解散

※アクセスは JAXA の HP（ http://fanfun.jaxa.jp/visit/chofu/access.html）等でご確認ください。

スクール担当 : 運営・学術委員会 若手ネットワーク分科会

佐々木澄（清水建設），松宮央登（電力中央研究所）

\section{「風環境に関する情報発信研究会」委員公募のお知らせ}

このほど,一般社団法人日本風工学会において,「風環境に関する情報発信研究会」の設置が認められました。 下記のように活動を開始しますので，参加希望の方はご応募いただきますよう，ご案内申し上げます。

・ 名称：風環境に関する情報発信研究会

・ 活動期間 : 平成 30 年 4 月〜平成 32 年 3 月

・ 主查 : 富永禎秀 (新潟工科大学), 幹事 : 白澤多一 (大妻女子大学)

開設趣旨：

2005～2017 年度の「都市の風影響評価研究会」の活動を通じて，風の都市生活への影響を適切に予測・評価 する上での課題を明らかにし，その対応策などを提示してきた。しかしながら，それらの研究成果が，実務的 な立場で風環境の予測・評価に携わる人や，風環境について不安や不満を持つ一般市民に十分に理解されてい るとは，残念ながら言えない実情がある。学会 HP の風環境に関する情報発信も社会のニーズに対して現状で は十分とは言えない。また風環境に関する出版物も, 専門家向けとしては 1993 年「都市の風環境評価と計画一 ビル風から適風環境まで一」（日本建築学会），一般向けとしては，2005 年「ビル風の基礎知識」（風工学研究 所）以降は無い状況である。以上のことから，風環境に関する最新の研究成果や知見を，分かりやすい形で学 会以外の層にアピールするための情報発信を，組織的に進める必要があると考えるに至った。

本研究会では，これまでの本会を中心とする最新の学術的知見を再整理し，都市の風環境の適切な予測・評 価方法等について，広く社会に理解してもらうための情報発信の方法を検討し，それを具現化することを目的 とする。情報発信の方法としては, 書籍, Web サイト (学会 HP), リーフレット等の形態が考えられる。また 情報発信のための意見集約を通じて, 各種の課題に対する研究者間の合意形成を促進することも目的の一つで ある。

活動概要 :

1 年目は, 3 ケ月に 1 回程度の研究会を開催し, 研究成果の情報発信に関するコンセプトを明確にするとと もに，具体的なメディアやコンテンツ，その作成体制を計画する。また必要に応じて本学会会員内外の専門家 の情報提供を受ける。これらの検討結果に基づいたスケジュールにより，出版やWebによる情報発信のための 準備を行う。

2 年目以降に, 1 年目の計画に基づいて, 具体的なコンテンツ作成作業に取り掛かる。適宜, 本学会会員等 の外部の意見も聞きながら，完成させ，情報発信を進める。

- 参加申し込み先 :

幹事 白澤多一（大妻女子大学）：shirasawa@otsuma.ac.jp 


\section{「実大ストームシミュレータの設計と要素技術に関する研究会」委員公募のお知らせ}

このほど, 一般社団法人日本風工学会において「実大ストームシミュレータの設計と要素技術に関する研究 会」の設置が認められました。下記のように活動を開始しますので, 参加希望の方はご応募いただきますよう, ご案内申し上げます。

・名称 : 実大ストームシミュレータの設計と要素技術に関する研究会

・活動期間 : 平成 30 年 4 月〜平成 32 年 3 月

・活動方法 : 年間 3 回程度の会議, および ML 等による情報共有, 意見交換

・開催場所 : 参画者が参集容易な東京とする。

・主査 : 田村幸雄 (東京工芸大学)

\section{【研究会設置の背景】}

世界の自然災害による経済的損失の $70 \sim 80 \%$ は，八リケーン，台風等の風水害に起因すると言われている。 多くの場合, 豪雨や高潮などの水災害と伴う複合災害である。火災, 降雪, 降霄などによる災害も強風との関 連性が深い。そのような災害の多くは，構造設計のなされない木造住宅や低層鉄骨建物である。これらの被害 を低減することは経済的損失の軽減だけではなく, 安全・安心な地域作りには不可欠な課題である。

従来，建築物の耐風性の検討は，縮尺模型を用いた風洞実験や圧力チャンバー等を用いた部材試験(通常は漸 増載荷)に基づいて行われてきた。しかし, それらの実験結果は, 様々な仮定の上での結果にしか過ぎず, 現象 を必ずしも正しく反映したものとは言えない。精度よく現象を把握するためには，実スケールで外装材仕上材 から構造骨組, 基礎に至るまでの全体システムの性能を評価する以外にない。火災や降雨, 降雪, 降雱などに ついても同様である。したがって，実大スケールで現象を再現できる「実大ストームシミュレータ」の建設が 強く望まれている。

このような背景の下，本研究会主查(田村)が提案した「実大ストームシミュレータ・気象災害サイエンスパ ーク」の建設が，2014 年日本学術会議において「速やかに実施するべき重点大型研究」として選定された。こ れを受けて，2014 年から 2018 年 3 月まで，「実大ストームシミュレータ研究会」として活動を行ってきた。本 研究会はその活動をさらに発展させ，実大ストームシミュレータ計画の実行に向けた検討を行う。

\section{【研究会の目標と実施内容】}

上記の「実大ストームシミュレータ」計画を実行に移すには，施設の設計を具体化するとともに，要素技術 に関する検討が必要不可欠である。

本研究会では, 初年度となる平成 30 年度には下記の項目について研究を実施する。

(1) 国内外（特に海外）における大型実験施設の設置および運営状沉に関する情報取集

（2）国内外（特に海外）における大型実験施設の要素技術に関する情報収集

(3) 上記実大ストームシミュレータに必要な要素技術の明確化

- 参加申し込み先 :

幹事 西嶋一欽（京都大学防災研究所）：nishijima.kazuyoshi.5x@kyoto-u.ac.jp 


\section{「耐風構造教材制作研究会」委員公募のお知らせ}

このほど, 一般社団法人日本風工学会において「而風構造教材制作研究会」の設置が認められました。下 記のように活動を開始しますので，参加希望の方はご応募いただきますよう，ご案内申し上げます。

- 名称：耐風構造教材制作研究会

・ 活動期間 : 平成 30 年 4 月 平成 32 年 3 月

・活動方法 : 主としてメールで情報交換を行い, 年 2 回の研究会を開催して成果の確認を行う。

- 主査 : 西村宏昭（京都大学防災研究所）

\section{【研究会設置の背景】}

風工学会会員の減少傾向が続いている。風工学に対寸る関心が薄れているのが大きな原因である。大学に おいては耐風構造の講座が少なくなっており, 風工学の知識の普及が底辺から進まない。実務面においても 而風構造は特殊な専門領域であり, 専門家のみが問題を解決すれば良いという風潮が広がっている。これに 歯止めを掛けるためには, 底辺を広げる方策しかないと考えられる。そのため, 教育課程に耐風構造のキャ リクラムを導入しやすくする。最終的には，単元的な講義用文書資料を整えなくてはならないが，その前身 として実験教材を制作する。

耐震構造の分野では, 1 質点または 2 質点の簡単な振動模型を手で摇すり, 構造物振動の原理を初学者に理 解させることなどは広く行われているが，耐風構造の分野ではそうした単純な模型を用いて風が物体に作用 する現象を示すことは少なく, 観念的な理解の強制に終始する。初学者の興味は物理的な現象から発するも のであるから, 風に伴う現象を実際に目で見て手で触って, 自ら理解することは極めて重要であるに違いな い。

\section{【研究会の目標と実施内容】}

当研究会では, 次世代教育用教材として風洞実験ができる実験装置を試作する。装置は机上に置くことが できる程度の大きさ（全長 $1 \sim 1.5 \mathrm{~m} ）$ とし, 送風機と計測機器をセットで開発する。送風機は市販の扇風機に 拡散筒と縮流筒を付けた簡易な風洞とする。風量の調整は扇風機に付いている強・中・弱の 3 段階程度で良 い。計測機器はマイコンを中心として, 圧力センサー, カセンサー, 変位センサーなどを組み込めるものと する。これらの開発に関する基本的な技術課題は解決できている。コンピュータ用冷却ファンを用いた小型 風洞の制作，マイコンを用いた圧力，力，変位量の測定は実績があるので，拡張・応用は容易である。

高校, 大学, 一般教養向けそれぞれに必要な計測の目標を決め, 風洞の制作と, 測定マニュアルの整備, 試行実験を行って，充実した教材を作る。成果としての教材は，出前講義や貸し出しなどに利用する。

- 参加申し込み先 :

幹事 吉田昭仁（東京工芸大）yoshida@arch.t-kougei.ac.jp 


\section{学術研究会の公募のお知らせ}

運営・学術委員会では, 平成 30 年度以降に発足させる学術研究会を公募致します。

学術研究会は風工学分野における研究振興を目的としたもので, 現在「風環境に関する情報発信研究会」,「実 大ストームシミュレータの設計と要素技術に関寸る研究会」,「瞬間風速の計測・予測技術研究会」「建築物 内外の圧力分布に関する研究会」「而風構造教材制作研究会」の 5 つの研究会が活動中です。会員各位の積極 的なご応募をお待ちしております。

申込書（書式自由）に必要事項（下記参照）を記入の上，お申し込み下さい。応募は随時受け付けます。運 営・学術委員会で審査し承認された後, 発足となります。

学術研究会の運営規程については, ホームページをご参照下さい。なお, 研究会の成果を発表・刊行するに あたって, 予算措置が必要な場合には, 別途申請することができます。また, 研究会終了後に研究成果の刊行 等を目的とした研究会を新たに申請することができます。

\section{1. 申込先}

一般社団法人日本風工学会 運営・学術委員会 幹事 日本大学 長谷部寛 (hasebe@civil.cst.nihon-u.ac.jp)

\section{2. 申込書記入事項}

（1）主查予定者および連絡責任者（氏名，所属，連絡先）

(2) 学術研究会名

（3）活動予定期間

(4) 開設趣旨

(5) 活動概要

（6）必要な予算見込み（上限 20 万円／年，交通費は原則として予算の $50 \%$ 以下）

(7) メンバー案（公募を前提として下さい）

\section{3. 問い合わせ}

不明な点につきましては，運営・学術委員会幹事（上記申込先と同じ）にお問い合わせ下さい。 


\section{一般社団法人日本風工学会 \\ 第4期（通算第21期）第9回理事会 議事録}

1. 日 時: 平成29年12月 15 日（金） 15 時30分～18時45分

2. 場 所: 日本大学理工学部駿河台校舎 5 号館2階523会議室

3. 出席者 : $\bigcirc$ : 出席, $\bigcirc$ : 久席

会 長: $\bigcirc$ 野村卓史

理 事: ○石原 孟, ○植松 康, ○奥田泰雄, ○勝地 弘, ○才村吉郎, ○小林文明, ○白土博通,

富永禎秀, ○中村 修, ○藤部文昭, ○松井正宏, ○丸山 敬, ○持田 灯, ○山田 均

監 事: ○近藤宏二, ○西村宏昭

事務局 : ○北川徹哉, ○中藤誠二

\section{4. 配布資料}

21-9-0 第4期（通算第21期，平成28年度-平成29年度）第9回日本風工学会理事会議事次第……… (事務局)

21-9-1 一般社団法人日本風工学会第4期（通算第21期）第8回理事会議事録（案）……………. (事務局)

21-9-2 平成29年度 中間会計報告…………………………………… (財務担当理事, 事務局)

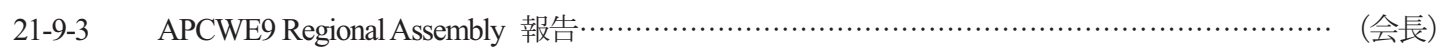

21-9-4 第4期（通算第21期）第7回（平成29年度3回） 一般社団法人日本風工学会運営 ・学術委員会議事録 (運営・学術委員会)

21-9-5 平成29年度代表委員選挙結果について………………………………… (運営・学術委員会)

21-9-6一般社団法人日本風工学会代表委員選出に関する細則……………………… (運営・学術委員会)

21-9-7 平成30年度 一般社団法人日本風工学会年次研究発表会・定時社員総会・懇親会のお知らせ

21-9-8 平成30年度 年次大会 経費一覧（概算）……………………………… (運営・学術委員会）

21-9-9 一般社団法人日本風工学会研究委員会設置申請書………………………… (運営・学術委員会)

21-9-10日本風工学会風㷋害調査連絡委員会第41回（平成29年度第2回，第21期第6回）議事録案

(風㷋害調查連絡委員会)

21-9-11日本風工学会風㷋害研究会第80回（平成29年度 第2回）議事次第……… (風災害調査連絡委員会)

21-9-12-1＼cjkstart想定される改革案の比較 \#2（風工学シンポジウムWG）………………………….... (会長)

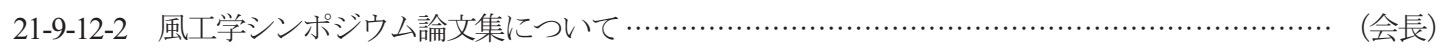

21-9-12-3 一般社団法人北海道開発技術センターおよび日本雪工学会の技術論文投稿に関する覚書…… (会長)

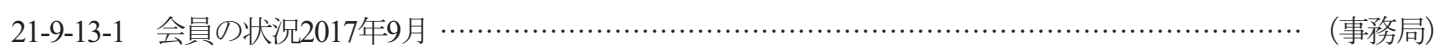

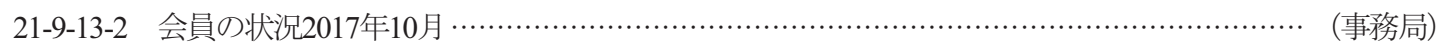

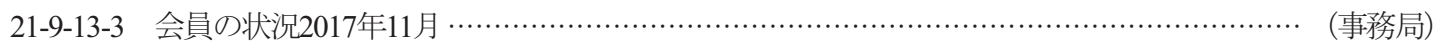

21-9-13-4 年会費未納者一覧および年度末退会申出・年度末自動退会一覧 …………………….... (事務局)

21-9-14グランド再生可能エネルギー2018国際会議＼cjkstart協賛名義のお願い……………………… (事務局)

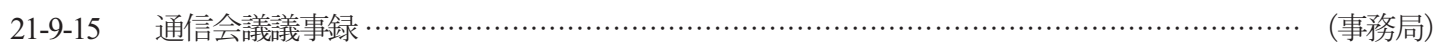

<通信会議（2017年6月28日～9月20日）＞

21-9-16＼cjkstart風工学シンポジウム論文集に関する検討（中間報告）…………………………… (会長)

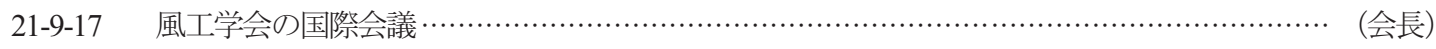




\section{5. 議事}

理事14名（理事15名の過半数は8名）が出席し, 定款第29条第1項により第9回理事会が有効に成立していること を確認した。定款第31条に従い，会長が第9回理事会の議長となり議事を進めた。

\section{1 審議事項}

(1) 理事会議事録署名人について

- 定款第33条第2項に従い，議長から第9回理事会の議事録署名人を以下のものとする案について諮ったところ, 全員異議なく承認した。

議事録署名人 丸山敬 理事

（2）第1号議案 第4期第8回理事会議事録確認（資料21-9-1 事務局）

・一部修正のうえ，全員一致で承認した。

（3）第2号議案 平成29年度 中間会計報告（資料21-9-2 財務担当理事，事務局）

・北川事務局長より，中閒会計について説明があり，全員一致で承認した。準備金からの取り崩しについて質問 があり，事務局より理事会ですでに説明して承認されているとの回答があった。

(4) 第3号議案 APCWE9 Regional Assembly 報告（資料21-9-3 会長）

・野村会長より，APCWE9 Regional Assemblyにおいて，日本も立候補した次回APCWEの開催は投票により中国 の成都に決まったこと，次期Regional CooridnatorはThe Hong Kong Polytechnic University のYou-Lin Xu教授が選 出されたとの報告があり，全員一致で承認した。

(5) 第4号議案 運営・学術委員会活動報告 (資料21-9-4 白土理事)

・白土理事より, 運営・学術委員会活動報告について説明があり, 全員一致で承認した。

（6）第5号議案 代表委員選挙結果について (資料21-9-5 6 白土理事)

・白土理事より，代表委員選挙結果について説明があり，全員一致で承認した。

・白土理事より，代表委員選出に関する細則に関して，下記の文言を追加する修正について説明があり，全員一 致で承認した。

第4条第4項「ただし，10月15日が土曜日，日曜日，祝日の場合は15日以降直近の平日とする。」を追加。

(7) 第6号議案 平成30年度 一般社団法人日本風工学会年次研究発表会・定時社員総会・懇親会について (資料 21-9-7 8 白土理事)

・白土理事より, 来年度の年次研究発表会・定時社員総会・懇親会について説明があり，全員一致で承認した。

(8) 第7号議案 研究委員会設置申請について (資料21-9-9 白土理事)

・白土理事より,「構造物内外の圧力分布に関寸る研究会」（主査：松井正宏，幹事：染川大輔）の設置申請につ いて報告があり, 全員一致で承認した。松井理事より, 委員は今後公募予定であり, 構造と環境の分野間の研 究の交流を活発にするために，両方の研究者をミックス寸る形の体制を予定しているとの説明があった。 
(9) 第8号議案 編集・広報委員会活動報告（奥田理事）

・奥田理事よりJ-Stage3の查読システムへの応募は取り止めることとしたことが報告され，全員一致で承認した。

(10) 第9号議案 表彰委員会報告 (石原理事)

・石原理事より，学会賞に関する今後の日程について説明があり，全員一致で承認した。

(11) 第10号議案＼cjkstart風災害調查連絡委員会活動報告（資料21-9-10 小林理事)

・小林理事より，風災害調査連絡委員議事録案について説明があり，全員一致で承認した。

(12) 第11号議案 風災害研究会活動報告議事録案（資料21-9-11 小林理事)

・小林理事より, 風災害研究会議事録案について説明があり, 全員一致で承認した。風災害調査時に着用寸る「日 本風工学会」名が入ったビブスは風災害研究会の委員の使用希望者には無償で配布し, それ以外についてはこ れから対応するとの説明があった。なお，風災害研究会の委員の研究室の学生等もこのビブスを着用してよい とするとの説明があった。

(13) 第12号議案 風工学シンポジウム論文集の改革案について (資料21-9-12-1〜3 野村会長)

・野村会長より, 風工学シンポジウム論文集の改革案について説明があった。風工学シンポジウム論文集の位置 づけについて, 風工学会論文集との関係を中心に, 二重投稿の扱い, 分野閒の対応の違い, 他学会の動向など, 多方面の観点から議論がなされた。引き続き理事会にて継続審議とすることとした。

(14) 第13号議案 会員の状況（資料21-9-13-1～3 事務局)

・平成29年9月から11月までの会員の異動状況が報告され，定款第6条に従い，1名（正会員1名）の入会を，全員 一致で承認した。

＜通信会議（2017年9月21日〜12月15日）＞

(15) 第14号議案 風工学シンポジウム論文集に関する風工学シンポジウム検討WGの検討状況(資料21-9-16 野 村会長)

・野村会長より，風工学シンポジウム論文集に関する風工学シンポジウム検討WGの検討状況について説明があ り，第9回理事会にて審議することとした。

(16) 第15号議案 IAWE アジア太平洋地域次期 Regional Cooridnator について (野村会長)

・野村会長より, APCWE9で開催されるアジア太平洋地域の Regional AssemblyにおけるIAWEアジア太平洋地域 次期Regional Cooridnatorの選出について提案があり，全員一致で承認した。

(17) 第16号議案２021年APCWE10 開催国への立候補について (資料21-9-17 野村会長)

・野村会長より，2021年APCWE10 開催国への立候補に関して発議があり，立候補について賛成の意見が多くあ り，立候補することで合意が得られた。また開催地は京都（議長：白土理事）とすることが承認された。

\section{2 報告事項}

以下の事項について報告があった。

（1）会員の状況（資料21-9-13-4 事務局）

・会員の状況について報告があった。 
（2）グランド再生可能エネルギー2018国際会議＼cjkstart協賛名義のお願い（資料21-9-14 事務局)

・事務局より承諾済みとの報告があった。

(3) その他

・松井理事より田村幸雄先生が中国工程院，外籍院士に選出されたとの報告があった。

(4) 次回理事会開催予定

・次回の理事会は下記の日程で開催することとした。

日時 : 3月19日15時30分

場所 : 未定

\title{
6. 閉会
}

以上をもって議案全部の審議を終了したので，18時45分に閉会した。

この議事録が正確であることを証するため，議長並びに議事録署名人はこれに署名押印する。

平成29年12月15日

一般社団法人日本風工学会

\begin{abstract}
議長 代表理事 野村 卓史 印
\end{abstract}
議事録署名人 丸山 敬 巴舟

監事西村 宏昭 团 


\section{一般社団法人日本風工学会 第 4 期（通算第 21 期）第 8 回運営 · 学術委員会 報告}

口日 時: 平成 30 年 2 月 18 日（日） 13:00 14:55

口場 所：日本大学理工学部お茶の水校舎 11 階 C1101 会議室

口出欠 : (○出席, ○欠席 : 敬称略)
○白土博通 (委員長)
○持田 灯 (副委員長)
○村吉郎（副委員長）

$\bigcirc$ 片岡浩人

○佐々木澄

○鈴木 修

田中英之

南雲洋介

本田明弘

$\bigcirc$ 松宮央登

丸山 敬

吉田昭仁

○長谷部寛 (幹事)

口議事要旨：

1) 前回議事録の確認

・誤字を修正した上で承認した。

2) 理事会報告

・第 4 期（通算第 21 期）第 9 回理事会（平成 29 年 12 月 15 日開催）の報告があった。

3) 平成 29 年度優秀修士論文賞の受賞候補者の選出

・平成 29 年度優秀修士論文賞の授賞候補者について審議を行った。慎重な審議の結果, 3 名を優秀修士論文賞 授賞候補者として，理事会に諮ることとなった。

4) 平成 30 年度年次研究発表会準備状況の確認

・準備状況が報告された。

・会告案を承認した。

5) 第 10 回若手スクール

・年次研究発表会の前日にJAXA 調布航空宇宙センターで実施することが報告された。

6) 学術研究会の継続申請

・現在活動中の学術研究会の活動期間を確認した。

・「実大ストームシミュレータ研究会」の継続申請を議論した。

・「都市の風影響評価研究会」が, 本年度でいったん活動を終了し,「風環境に関する情報発信研究会」を新設 することについて議論し，設置を承認した。

7) 平成 29 年度運営・学術委員会活動報告案

・記載内容が確認された。

8) 平成 30 年度運営・学術委員会予算案

・予算申請額が承認された。

9) その他

・APCWE10 の開催地が西南交通大学で決定したことが報告された。

（文責 : 長谷部寛） 


\section{一般社団法人日本風工学会 第 4 期（通算第 21 期）第 7 回編集 ·広報委員会 報告}

曰日 時: 平成 29 年 12 月 18 日（月） $13: 30 \sim 16: 10$

口場 所：東京大学本郷キャンパス 工学部一号館セミナーA 室

口出席者：(○出席, ○欠席, 敬称略)

○奥田泰雄（委員長）门松井正宏 (副委員長)，○喜々津仁密（幹事）,

○相原知子, ○荒木啓司, ○片桐純治, ○岸田岳士, ○作田美知子,

○佐々浩司， ○佐々木亮治， ○佐藤大樹， ○杉山貞人， ○竹見哲也,

○谷口徹郎, ○富永禎秀, ○西嶋一欽, ○野田 博, ○松田一俊,

○午知已, 敦

議事等：

1. 確認・報告事項

1-1 前回（第 4 期第 6 回）議事録案の確認

- 前回議事録案を確認し, 了承された。

$1-22018$ 年 1 月号原稿状況の報告

・学会誌・論文集への掲載予定の記事・論文ならびに原稿提出状況について説明があった。論文は 2 編の 掲載である。

・「各種お問い合わせ先・連絡リスト」掲載の代表委員会の委員構成を更新する。

$1-3$ 論文査読状況の報告

・論文の審査状況について説明があった。

・ベストペーパー賞候補論文の推薦方法を確認した。

$1-4$ その他の報告

・J-Stage3 の査読システム利用についての申請は取り止めることとした。

・広告の契約状況について報告があった。

・今後, 主な国際会議の報告については, 国際会議担当が執筆責任者を決定することとした。

2. 討議事項

2-1 2018 年 4 月号の編集内容について

・学会誌・論文集の内容について確認した。特集は平成 30 年度年次研究発表会（オーガナイズドセッショ ン) である。

・優秀修士論文賞の選考経過に関する報告を掲載する。

・ 各原稿の締め切りは 2 月 5 日とする。

$2-2$ 今後の巻頭言・特集の内容について

・今後掲載予定の巻頭言の執筆依頼者，特集記事の内容，連載記事の企画について討議した。

2-3 その他の検討について

・ 二重投稿の扱いに対する内規の変更について討議した。また, 査読に関する内規の修正に伴い, 1 月号 より論文集の執筆要領を更新する。

・学会ホームページの改修作業について討議した。 
3. その他

・次回は 2 月下旬から 3 月中旬に開催予定とする。

(文責 : 喜々津仁密)

\section{一般社団法人日本風工学会 第 4 期（通算第 21 期）第 8 回編集 ·広報委員会 報告}

口日 時: 平成 30 年 3 月 5 日（月） $10: 30 \sim 12: 30$

場 所: 東京大学本郷キャンパス 工学部一号館セミナーA 室

口出席者：(○出席, ○欠席, 敬称略)
○奥田泰雄（委員長）
○松井正宏 (副委員長)
喜々津仁密 (幹事),

○相原知子,

○荒木啓司，

○片桐純治,

○岸田岳士,

$\bigcirc$ 作田美知子,

○佐々浩司, ○佐々木亮治,

○佐藤大樹,

○杉山貞人，

○竹見哲也,

○谷口徹郎, ○富永禎秀,

○西嶋一欽,

○野田 博,

○松田一俊,

○人木知已， 山口敦

\section{議事等：}

1. 確認・報告事項

1-1 前回（第 4 期第 7 回）議事録案の確認

- 前回議事録案を確認し, 了承された。

1-2 2018 年 4 月号原稿状況の報告

・学会誌・論文集への掲載予定の記事・論文ならびに原稿提出状況について説明があった。論文は 4 編の 掲載である。

$1-3$ 論文查読状況の報告

・論文の審查状況について説明があった。

$1-4$ その他の報告

・広告の契約状況について報告があった。

・学会HP の更新作業の状況について報告があった。

\section{2. 討議事項}

2-1 2018 年 7 月号の編集内容について

・学会誌・論文集の内容について確認した。特集は「風力発電（案）」である。

・ 各原稿の締め切りは 5 月 15 日とする。

$2-2$ 今後の巻頭言・特集の内容について

・ 今後掲載予定の巻頭言の執筆依頼者，特集記事の内容，連載記事の企画について討議した。

2-3 その他の検討について

・査読要領及び投稿規程の改定について討議した。 
3. その他

・次回は次期委員と合同での開催となる。6月中旬の予定で日程を調整する。

（文責 : 喜々津仁密）

\section{一般社団法人日本風工学会 第 4 期（通算第 21 期）第 4 回表彰委員会 報告}

口日 時: 平成 30 年 3 月 6 日（火） 9 時 30 分 12 時 30 分

口場 所：東京大学工学部 1 号館 4 階 セミナーA 会議室

口出席者（○出席, ○欠席, 敬称略）：

○石原 孟 (委員長), ○勝地 弘 (副委員長), ○植松 康, ○小林文明, ○丸山 敬,

○土博通, ○富永禎秀, ○山崎智之, ○松井正宏, ○山口 敦 (幹事)

\section{口議事等}

1. 前回議事録（案）について

・ 前回議事録（案）の報告があった。

2. 日本風工学会 学会賞等の候補の応募状況について

・平成 30 年 1 月 31 日の締め切り日までに応募された論文等について, 報告があり, 候補資格者の確認が行 われた。

3. 日本風工学会 学会賞等の選考について

- 審議の結果, 学会賞 (功績賞) 2 件, 学会賞 (論文賞) 1 件, 研究奨励賞 1 件, 技術開発賞 1 件, デザイ ン賞 1 件を授賞候補として，理事会に推薦することとした。

・各賞ごとの授賞理由書執筆者の指名が行われた。

以上

（文責 山口 敦） 


\section{一般社団法人日本風工学会 第 4 期（通算第 21 期）第 7 回風災害調査連絡委員会 報告}

口日 時: 2017 年 12 月 22 日（金） $13: 00 \sim 15: 00$

口場 所：東京理科大学森戸記念館第 1 会議室

口出欠者：○小林文明 (委員長)，○丸山 敬 (副委員長)， ○野田 稔 (幹事), ○奥田泰雄， ○喜々津仁密， ○村吉郎，○友清衣利子，○西嶋一欽，○松井正宏

\section{口議事等：}

1. 風災害調查連絡委員会および風災害研究会の予算執行状況についての中間報告があった。

2. 2017 年アニュアルレポート執筆の締め切りが案内された。

3. 台風 18 号の速報記事が完成し，学会誌 1 月号に掲載されることが報告された。

4. 3 月の委員会はWRDM の開催時期とも重なっているため, WRDM 前日に開催することとし, 風災害研究 会の委員にはWRDMのツアーへの参加を促し, WRDMのレセプションの後に風災害調査連絡委員会と風 災害研究会を開くこととした。

（文責 野田 稔）

\section{一般社団法人日本風工学会 第 4 期（通算第 21 期）第 8 回風災害調査連絡委員会 報告}

口日 時：2018 年 3 月 11 日（日） $18: 00 \sim 19: 00$

口場 所 : 東北大学青葉記念会館

口出欠者：○小林文明 (委員長), ○丸山 敬 (副委員長), ○野田 稔 (幹事), ○奥田泰雄, ○喜々津仁密，○村吉郎，○友清衣利子，○西嶋一欽，○松井正宏

\section{口議事等 :}

1. 風災害調查連絡委員会および風災害研究会の今年度の会計収支について報告があつた。

2. 社員総会に向けた今年度の活動報告について内容を確認し承認した。

3. 来年度の活動内容について, 通常の活動として, 4 回の定例会と 2 回の一般公開講演会を開催し, 加えて, フォーラムの開催および強風災害の変遷と教訓の改定に向けた準備活動, 藤田哲也博士の資料のアーカイ ブ化を進めることとした。 
今後開催予定の国際会議等

*) IAWE Conference

*The 7th International Symposium on Computational Wind Engineering (CWE 2018) Seoul, Korea, June 18-22, 2018

*The 15th International Conference on Wind Engineering (15ICWE)

Beijing, China, September 1-6 (Tentative), 2019 